\title{
Big payoff from high-temperature superconductor patents
}

\section{Tokyo}

Du PonT Company last week paid the University of Houston \$1.5 million dollars for exclusive rights to Professor Paul Chu's high-temperature superconductor patent applications. The company is betting that Chu's group will win the race for patent rights to the yttrium-based copper oxides discovered by Chu last year. If and when Chu receives the patent, DuPont will add another $\$ 3$ million to the payment.

A survey of patent applications for the new superconductors being constantly upTechnology Group (see below) suggests that there will be some complex legal battles over patent priority and coverage.

In Europe and Japan, patent applications are published 18 months after filing (or after the earliest priority date claimed) and so can be monitored. US patents, on ed and are harder to track. But many of the published European and Japanese patent applications include priority claims for the key US patents and so give away US filing dates.

Vear's survey reveals that, among the patent applications now public, AT \& T was first to file an application for oxide superconductors and devices made from dated by Christopher Vear of the British the other hand, remain secret until grantthem on January 9, 1987, followed three

yttrium- barium-copper oxide, he says. Chu will probably argue that the substitution of yttrium was "inventive" and led to a large increase in critical temperature.

IBM would appear to have missed the boat with its late patent application on January 23, 1987 for superconductors belonging to the lanthanum-bariumcopper oxide group. That certainly seems the case in Japan and Europe where the "first to file" rule applies to patent priority. But IBM may still get the US patent.

The United States gives priority to the "first to invent" in a rule which usually only applies to research carried out within the country. But, according to Vear, if IBM Zurich transferred laboratory notes to any of IBM's US laboratories and the notes were understood and experiments repeated, the invention would be "reduced to practice" in the United States and IBM can rely on Bednorz and Müller's October 1986 paper on lanthanumbarium-copper oxide for priority there. But the extent to which such a patent could be extrapolated to cover other oxide superconductors is an open question.

The weakest patent of all appears to be that filed by Tokyo University on 17 January 1987 . The patent only covers one form of lanthanum-barium-copper oxide. And, even if granted, would probably be

\begin{tabular}{|c|c|c|c|}
\hline \multicolumn{4}{|c|}{ High-temperature superconductor patent applications } \\
\hline Organization & Priority claimed & Countries filed & Coverage \\
\hline AT \& T & $\begin{array}{l}9.1 .87 \\
3.3 .87 \\
10.3 .87\end{array}$ & Europe, USA & $\begin{array}{l}\text { Two applications on a wide range of materials, methods } \\
\text { and devices. }\end{array}$ \\
\hline $\begin{array}{l}\text { University of } \\
\text { Houston }\end{array}$ & $\begin{array}{l}12.1 .87 \\
27.1 .87 \\
6.2 .87 \\
26.3 .87\end{array}$ & $\begin{array}{l}38 \text { countries } \\
\text { including USA, } \\
\text { Europe, and Japan }\end{array}$ & Wide range of materials and production methods. \\
\hline University of Tokyo & 17.1 .87 & Japan & Relates to single-phase LaBCO only. \\
\hline IBM & 23.1 .87 & Europe, USA, Japan & $\begin{array}{l}\text { Materials with LaBCO-type structure and stoichiometric } \\
\text { composition and methods of fabrication. }\end{array}$ \\
\hline MITI & $\begin{array}{l}27.1 .87 \\
20.2 .87 \\
5.3 .87 \\
11.6 .87 \\
30.8 .87\end{array}$ & $\begin{array}{l}12 \text { countries } \\
\text { including Japan, } \\
\text { Europe and USA }\end{array}$ & $\begin{array}{l}\text { Range of YBCO-type materials, including claimed room- } \\
\text { temperature superconductor, and methods of preparation. }\end{array}$ \\
\hline
\end{tabular}

Table compiled by Dr C. Vear of British Technology Group. days later by the University of Houston. These applications, however, relate to the lanthanum-barium-copper oxides discovered by Georg Bednorz and Alex Müller of IBM Zurich in 1986; yttriumbarium-copper oxide was not found by Chu until late January 1987 and he filed another patent application at that time.

The differences in stoichiometry, crystal structure and superconducting properties of these two types of oxide superconductor are likely to feature prominantly in disputes over patent priority and coverage. Vear expects AT\&T to argue that substitution of yttrium was "obvious". AT\&T's first US application does include the possibility of a form of of no commercial value. Japan's Ministry of International Trade and Industry on the other hand, has filed patents in 12 countries for yttrium-barium-copper oxide materials, including a claimed room-temperature superconductor, and the priority dates stretch back to 27 January 1987.

Despite the uncertainty, Chu's group is clearly confident of getting the patents for the yttrium-based superconductors. The group has filed patent applications in 38 countries, including some in Africa. And Julie Norris, a spokeswoman for the group, says they believe they are in a "strong position", otherwise "they would not be doing what they are doing".

David Swinbanks
Dear Bush and Dukakis..

\section{Washington}

LEADERS of US scientific societies representing more than three-quarters of a million scientists and engineers released a letter last week calling on the two presidential candidates to support "a strengthened and coherent science policy" in a new administration.

The letter stresses that problems "ranging from the destruction of the ozone layer ...to the spread of AIDS and restoration of the competiveness of US industry" rely on scientific and technological resources. Leadership, the letter says must come from the White House.

The letter comes from 23 scientific societies, ranging from the Acoustical Society of America to the American Vacuum Society. The leaders of three of the biggest groups - Val Fitch, President of the American Physical Society (APS), Howard Schachman, president of the Federation of American Societies for Experimental Biology, and Russell Drew, president of the Institute of Electrical and Electronics Engineers and governor of the American Association of Engineering Societies - told a news conference that they were asking for a strong science advisor to be appointed early in the next administration.

The three society chiefs all spoke highly of the Eisenhower and Kennedy eras, when science had had a strong voice through the Presidential Science Advisory Committee, a body scrapped by President Nixon.

Fitch, a Nobel Prize winning physicist from Princeton, pointed out that the government "should not have to rely on an independent society" for advice on such matters as directed-energy weapons, where APS was the first to provide authorative analysis.

Drew, president of Viking Instrument Corporation, argued that Congress had been forced to do the the administration's job in such legislation as the Omnibus Trade and Competitiveness Act. Among other measures, the act renames (from last week) the National Bureau of Standards as the National Institute of Technology and Standards and gives it new responsibilities for regional advanced technology outreach programmes. "A strong science and technology advisor will be needed to make them effective", said Drew.

The call for sounder advice seems unlikely to have much impact on the presidential race. A spokesman for the Republican party said that they were unlikely to send a formal reply to the letter as they receive "hundreds of letters like this".

Alun Anderson 